\title{
コンクリートの載荷時熱ひずみに及ぼす養生条件と水セメント比の影響 コンクリートの高温時特性に及ぼす水分の影響(その 2 ) \\ INFLUENCE OF CURING CONDITION AND WATER CEMENT RATIO ON LOAD-INDUCED THERMAL STRAIN OF CONCRETE
}

Influence of water content on properties of concrete in high temperatures Part 2

\author{
山下平祐*, 吉田 徹**, 宍倉大樹***, 常世田昌寿*, 平島 岳夫**** \\ Heisuke YAMASHITA, Toru YOSHIDA, Daiki SHISHIKURA, \\ Masatoshi TOKOYODA and Takeo HIRASHIMA
}

\begin{abstract}
In the present study, the influence of the curing conditions (air-dried, oven-dried and sealed curing) and water/cement ratios ( $40 \%$, $50 \%$ and $65 \%$ ) on the load- induced thermal strain (LITS) of concrete specimens was investigated. The relationship between the LITS and specimen weight loss was also evaluated in order to develop a comprehensive model for the LITS. It was clarified from the present study that LITS due to dehydration and decomposition was much larger than that due to water evaporation. And, the numerical model for the LITS was proposed as a function of the weight loss of the specimens.
\end{abstract}

\author{
Keywords : Concrete, High Temperature, Load Induced Thermal Strain, Weight Loss, Curing Condition \\ Water-Cement Ratio \\ コンクリート, 高温, 載荷時熱ひずみ, 重量損失, 養生条件, 水セメント比
}

\section{1. はじめに}

コンクリートが圧縮応力を受けながら温度上昇する際に生じる収 縮ひずみ（以下，載荷時熱ひずみと称す）は，同時に発生する熱膨 張ひずみを打ち消すほじ大きなものである ${ }^{1)}$ 。そのため, コンクリ 一ト系構造の耐火性を検討寸る際には, コンクリートの高温時応力 一ひずみ関係と熱膨張ひずみに加え, 載荷時熱ひずみの性状を把握 することが重要となる。前報（その1） ${ }^{2)}$ ではコンクリートの高温時 応力ーひずみ関係に及ぼす水分の影響について報告した。本報（そ の 2) では，コンクリートの載荷時熱ひずみに及ぼす水分の影響に ついて報告する。

載荷時熱ひずみ（LITS : Load-Induced Therma1 Strain）は, Khoury $ら^{3)}$ が提案したコンクリートの高温時ひずみ構成則に用いるひずみ 成分の一つであり，コンクリートが一定圧縮応力のもとで加熱され る際に生じるひずみの総和（Total Thermal Strain, 以下，全ひず みと称す）から，その熱膨張ひずみと初期応力ひずみを差引いたひ ずみとして定義されている。このことから載荷時熱ひずみは，温度 上昇に伴う弾性係数低下により生じる弾性ひずみやひび割れの増加 などにより生じる塑性ひずみ, 蒸発性水分の蒸発やセメント水和物
の脱水に伴い生じるクリープひずみなどを含む収縮ひずみと考えら れる。Khoury らのモデルのような，コンクリート系構造の火災応答 解析で使用することを目的とした構成則は他にも複数提案されてお り 4),5)，いずれのモデルでも載荷時熱ひずみに関係するひずみはコ ンクリートの温度を主要因とした数式モデルで表されている ${ }^{4)-6) 。}$ 一方，コンクリートの載荷時熱ひずみはセメント水和物の物理的・ 化学的反応の進行に伴い発生するため ${ }^{5), 7)}$, コンクリート中の水分 の影響を受けることが報告されている。例えば，事前乾燥により水 分を蒸発させたコンクリートの場合, $100^{\circ} \mathrm{C} \sim 250^{\circ} \mathrm{C}$ 程度の範囲で載

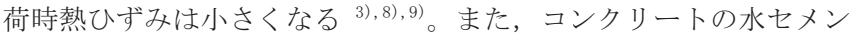
卜比が小さいほど載荷時熱ひずみは大きくなる ${ }^{10)-12) 。 し た か ゙ っ て, ~}$ 従来の温度を主要因とした数式モデルを水分条件の異なるコンクリ 一トに対して汎用的に適用することは難しい。一方，載荷時熱ひず みを高温下におけるセメント水和物の反応との関係で直接表すこと ができれば，両者の関係は前述した水分の影響を包含したものにな り，従来よりも汎用的な数式モデルを作成することが可能になると 考えられる。Sabeur ら ${ }^{13)}$ は，セメント水和物の脱水量を TGA（熱重 量測定）から得た重量減少で表し，載荷時熱ひずみとの関係を数式

\footnotetext{
本論は，文献 22)，23）に発表したものに，検討を加えてまとめたものである。

* (一財) 建材試験センター 博士 (工学)

** 千葉大学大学院工学研究科 大学院生

*** (一財) 建材試験センター

**** 千葉大学大学院工学研究科 教授. 博士 (工学)

Japan Testing Center for Construction Materials, Dr.Eng.

Grad. Stud., Graduate School of Engineering, Chiba Univ.

Japan Testing Center for Construction Materials

Prof., Graduate School of Engineering, Chiba Univ., Dr.Eng.
} 
モデル化している。そして, この数式モデルが, 圧縮強度 40〜 $120 \mathrm{~N} / \mathrm{mm}^{2}$ のコンクリート試験体（寸法：直径 $104 \times$ 高さ $300 \mathrm{~mm}$ ) の実 験データを追跡できると報告している。ただし, TGA で用いる微量 サンプルと試験体では, 脱水反応と温度の関係が異なるため, セメ ント水和物の脱水量は載荷時熱ひずみ測定時における試験体の重量 減少で表した方がより適切である。しかし, 載荷時熱ひずみと試験 体の重量減少の関係を検討した研究は見当たらない。さらに, コン クリート中の水分が載荷時熱ひずみに及ぼす影響について検討した 研究の多くは水セメント比が $40 \%$ 未満の高強度コンクリートを対象 としたものであり, 水セメント比が $40 \%$ 以上のより一般的なコンク リートを対象として, 養生条件や水セメント比の違いが及ぼす影響 を検討した研究は国内にはない。

以上を踏まえ, 本報では水セメント比が $40 \%$ 以上のコンクリート について, 養生条件および水セメント比の違いが載荷時熱ひずみに 及ぼす影響を検討するため，一定圧縮応力下で加熱されるコンクリ 一ト試験体の全ひずみを測定する実験（以下, 全ひずみ実験と称す） を行った。さらに, 全ひずみ実験と同じ試験体を用いて重量減少測 定実験も実施した。本報では，これらの実験結果を報告するととも に, 実験から得られた載荷時熱ひずみと試験体の重量減少の関係を 検討し, 水分条件の異なるコンクリートにも適用できる, 従来より も汎用的な載荷時熱ひずみの数式モデル作成を試みた。

\section{2. 試験体}

全ひずみ実験および重量減少測定実験で使用した試験体（寸法： 直径 $75 \times$ 高さ $150 \mathrm{~mm} ）$ は，前報 ${ }^{2)}$ で報告した試験体と同様に作製し たものである。表 1 に試験体の条件, 表 2 に試験体の呼称として本 報で使用する試験体名を示寸。試験体の調合, 養生方法の詳細は前 報 2)を参照されたい。実験実施時における試験体の材齢は 348 485 日である。なお，前報 ${ }^{2)}$ で報告したように，実験期間前後における 試験体の含水率や圧縮強度・弾性係数に大きな変化は確認されなか ったことから，試験体間の材齢の違いが実験結果に及ぼす影響は小 さいと考えられる。表 3 に, 試験体の実験前における単位体積重量 を示す。同条件の試験体間における単位体積重量のばらつき, およ び前報で使用した試験体との単位体積重量の差は $980 \mathrm{~N} / \mathrm{m}^{3}(0.1$ $\left.\mathrm{tf} / \mathrm{m}^{3}\right)$ 未満に収まった。表 4 に, 気乾試験体および封かん試験体の 含水率を示す。なお本報では, 試験体を $105^{\circ} \mathrm{C} て ゙ 14$ 日間乾燥するこ とによって生じた重量減少量を蒸発性水分量, 乾燥前の重量に対す る蒸発性水分量の割合である湿量基準含水率を含水率 $\left(\mathrm{R}_{\mathrm{wc}}\right)$ と称す。 気乾試験体の含水率は, 全ひずみ実験および重量減少測定実験で使 用した絶乾試験体の事前乾燥前後における試験体重量変化から算出 した。封かん試験体の含水率は, $105^{\circ} \mathrm{C} て ゙ ~ 14$ 日間乾燥した際に生じ た重量減少に対して, 実験準備中に生じた蒸発性水分の蒸発による 重量減少を差引いた值を用いて算出した。なお，実験準備は気乾状 態で約半日かけて行い, その間に生じた重量減少は, 準備前の重量 に対する割合で平均 $0.35 \%$ あった。

\section{3. 試験体の重量減少}

\section{1 重量減少測定実験}

全ひずみと試験体の重量減少の関係を把握するため，全ひずみ実 験と同条件の試験体による重量減少測定実験を, 試験体条件ごとに
表 1 試験体の条件

\begin{tabular}{|c|c|}
\hline $\begin{array}{c}\text { 水セメりト比 } \\
W / C(\%)\end{array}$ & $65,50,40$ \\
\hline \multirow{3}{*}{ 養生条件 } & 気中養生 \\
\hline & $\begin{array}{l}\text { 事前乾燥 } \\
\left(105^{\circ} \mathrm{C} \text { で } 14 \text { 日間) }\right.\end{array}$ \\
\hline & 封かん養生* \\
\hline
\end{tabular}

*封かん養生は $\mathrm{W} / \mathrm{C}=65 \%$ ので 実施した。
表 2 試験体条件ごとの試験体名

\begin{tabular}{|c|c|c|c|c|}
\hline & \multicolumn{3}{|c|}{$\mathrm{W} / \mathrm{C}(\%)$} \\
\hline & & 65 & 50 & 40 \\
\hline \multirow{3}{*}{$\begin{array}{l}\text { 養 } \\
\text { 年 } \\
\text { 条 } \\
\text { 件 }\end{array}$} & $\left.\begin{array}{c}\text { 気中養生 } \\
\text { 気乾試験体 }(\mathrm{A}) \\
\text { Air-dried }\end{array}\right)$ & $65 \mathrm{~A}$ & $50 \mathrm{~A}$ & $40 \mathrm{~A}$ \\
\hline & $\begin{array}{c}\text { 事前乾燥 } \\
\left(\begin{array}{c}\text { 絶乾試験体 (D) } \\
\text { oven-Dried }\end{array}\right.\end{array}$ & 65D & $50 D$ & 40D \\
\hline & $\left.\begin{array}{c}\text { 封かん養生 } \\
\text { 封かん試験体 (S) } \\
\text { Sealed }\end{array}\right)$ & $65 \mathrm{~S}$ & - & - \\
\hline
\end{tabular}

$\left(\mathrm{kN} / \mathrm{m}^{3}\right.$

表 3 試験体の単位体積重量

\begin{tabular}{|c|c|c|c|c|c|c|c|}
\hline 試験体名 & $65 \mathrm{~A}$ & $65 \mathrm{D}$ & $65 \mathrm{~S}$ & $50 \mathrm{~A}$ & $50 \mathrm{D}$ & $40 \mathrm{~A}$ & $40 \mathrm{D}$ \\
\hline \hline 最小值 & 21.8 & 21.3 & 22.4 & 22.1 & 21.4 & 22.5 & 21.8 \\
$(2.22)$ & $(2.17)$ & $(2.28)$ & $(2.25)$ & $(2.18)$ & $(2.29)$ & $(2.22)$ \\
\hline 最大值 & 22.0 & 21.7 & 22.7 & 22.4 & 21.7 & 22.7 & 22.1 \\
\hline 平均值 & $(2.24)$ & $(2.21)$ & $(2.31)$ & $(2.28)$ & $(2.21)$ & $(2.31)$ & $(2.25)$ \\
\hline$(2.23)$ & $(21.5$ & 22.6 & 22.2 & 21.6 & 22.5 & 21.9 \\
$(2.19)$ & $(2.30)$ & $(2.26)$ & $(2.20)$ & $(2.29)$ & $(2.23)$ \\
\hline
\end{tabular}

表 4 試験体の湿量基準含水率 $\mathrm{R}_{\mathrm{wc}}$

\begin{tabular}{|c|c|c|c|c|}
\hline 試験体名 & $65 \mathrm{~A}$ & $50 \mathrm{~A}$ & $40 \mathrm{~A}$ & $65 \mathrm{~S}$ \\
\hline \hline $\mathrm{R}_{\mathrm{wc}}$ & $2.10 \%$ & $2.73 \%$ & $3.19 \%$ & $6.08 \%$ \\
\hline
\end{tabular}

・表中の含水率は, 試験体条件ごとの平均值である.

2 回ずつ行った。重量減少測定実験では, 試験体を全ひずみ実験と 同じ加熱速度 $\left(1.5^{\circ} \mathrm{C} /\right.$ 分）で $800^{\circ} \mathrm{C}$ ま゙加熱しながら試験体重量の 測定を行った。実験に使用した実験装置を図 1 および写真 1 に示す。 実験では，箱型電気炉を用いて同種類の試験体を 2 体ずつ，合計 4 体の加熱を同時に行い, 同種類の試験体のうちの 1 体で試験体重量, 残りの 1 体で試験体内部温度を測定した。試験体は，電気炉の上方 からステンレスワイヤーで吊るしたステンレス籠に入れた状態で加 熱した。電気炉からの直接の輻射を避け内部温度差を緩和するため, 試験体の外周にはセラミック製耐火クロスを巻きつけた。重量測定 用試験体は, ワイヤーの途中にロードセルを介して吊るした。なお， ロードセルは, 炉蓋（厚さ $25 \mathrm{~mm}$ のセラミックファイバーブランケッ 卜+厚さ $25 \mathrm{~mm}$ のケイ酸カルシウム板) から $400 \mathrm{~mm}$ 以上離して設置し, 扇風機で微風を与え空冷した。これによりロードセル周辺の䨌囲気 温度が補償温度上限值 $60^{\circ} \mathrm{C}$ 未満となるようにした。また, 試験体を 設置する際には，炉蓋がワイヤーに干渉しないように注意した。温 度測定用試験体には K 熱電対を埋め込み，重量測定用試験体の内部 温度は温度測定用試験体と同じとみなした。図 2 に，重量減少測定 実験における試験体内部温度測定位置を示す。電気炉の加熱制御は, 4.1 節に後述する全ひずみ実験と同じく, 試験体の上下端部におけ る表面から深さ $6 \mathrm{~mm}$ の位置での温度（図 2 中の $\mathrm{T}_{1}, \mathrm{~T}_{2}$ ) が $1.5^{\circ} \mathrm{C} /$ 分 で昇温するように行った。図 3 に，実験時における試験体内部温度 と時間の関係の一例として, 封かん試験体の測定結果を示す。図 3 では，試験体の軸方向において上下端部よりも中央部の温度が低く なった。同様の傾向は全ての実験において見られ，実験時の試験体 内部の温度差は最大で $54^{\circ} \mathrm{C}$ となった。試験体内部温度を代表する 「試験体温度」は，全ひずみ実験と同じく，試験体表面から深さ $6 \mathrm{~mm}$ の位置で測定した温度の平均值とした。算出式を以下に示す。

$T_{W}=\left(T_{1}+T_{2}+2 \cdot T_{3}\right) / 4$

$T_{W}$ : 重量減少測定実験での試験体温度 $\left({ }^{\circ} \mathrm{C}\right)$,

$T_{1}, T_{2}, T_{3}$ : 試験体表面から深さ $6 \mathrm{~mm}$ での温度（図 2 参照） ( 


\section{2 重量減少と温度の関係}

重量減少測定実験では, 同条件の試験体による 2 回の実験でほぼ 同等な測定結果が得られた。図 4 に, 各実験条件における重量減少 率と試験体温度の関係を一例ずつ示す。重量減少率は下式より算出 した。

$R_{w l}=\left(W_{\text {init. }}-W_{\text {pres. }}\right) / W_{\text {init }} \times 100$

$R_{w l}:$ 重量減少率 $(\%)$,

$W_{\text {init }}$ : 重量測定用試験体の初期重量

$(14.0 \mathrm{~N}(1430.0 \mathrm{gf}) \sim 15.1 \mathrm{~N}(1538.5 \mathrm{gf}))$

$W_{\text {pres }}$ : 重量測定用試験体の測定時の重量

気乾試験体および封かん試験体の重量減少率は $100^{\circ} \mathrm{C}$ から急激に 増加する一方, 絶乾試験体の重量減少率は $200^{\circ} \mathrm{C}$ までほとんど変化 しなかった。気乾試験体および封かん試験体の急激な重量減少は, 重量減少率が表 4 に示寸各試験体の含水率に達寸ると緩やかになる

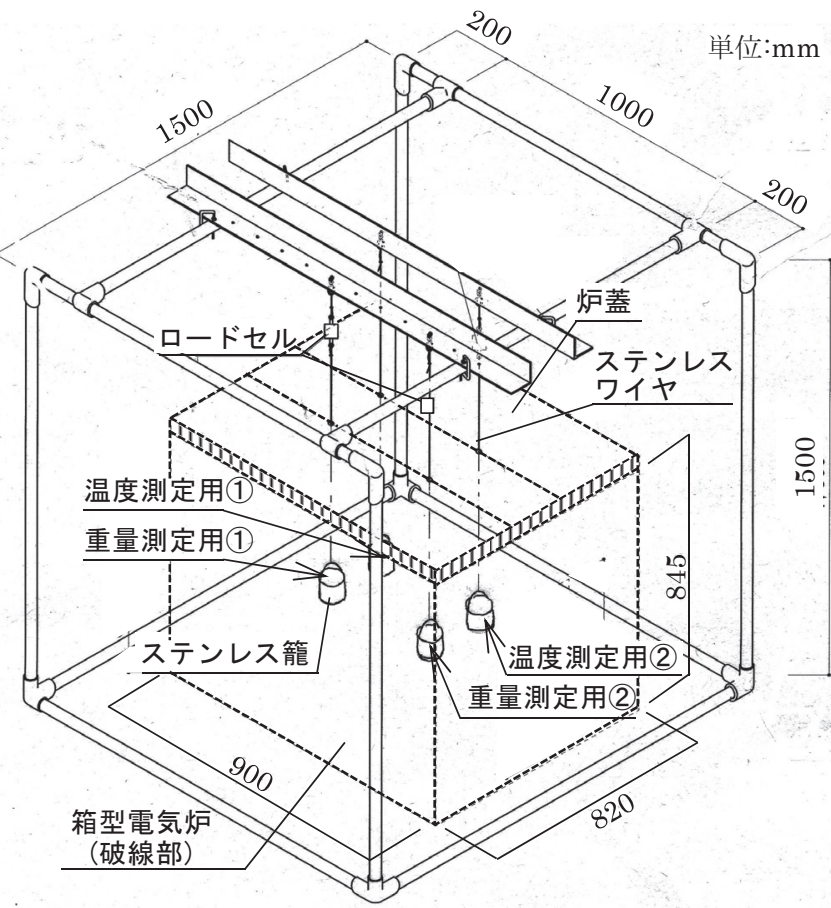

図 1 重量減少測定実験装置（概観）

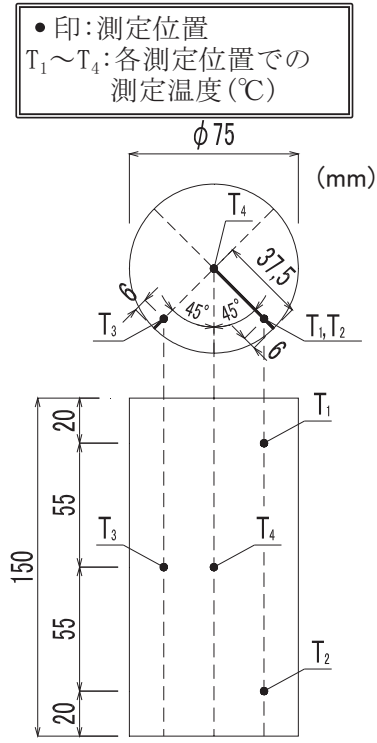

図 2 試験体内部温度測定位置 （重量減少測定実験）

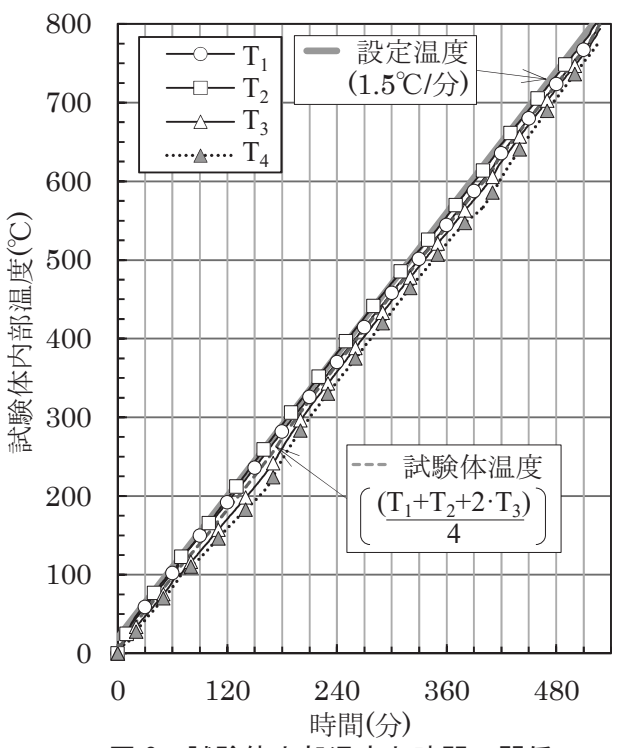

図 3 試験体内部温度と時間の関係 （重量減少測定実験）
ことから, 蒸発性水分の蒸発に因ると考えられる。蒸発性水分の蒸 発は, 気乾試験体では約 $200^{\circ} \mathrm{C}$, 封かん試験体では約 $250^{\circ} \mathrm{C}$ まで継続 した。気乾試験体の急激な重量減少が $100^{\circ} \mathrm{C} \sim 200^{\circ} \mathrm{C}$ 程度で発生する ことは既往の報告と一致する ${ }^{4), 14), 15)}$ 。200 ${ }^{\circ} \mathrm{C}$ からは絶乾試験体の重 量減少も始まる。これは, ケイ酸カルシウム水和物 (C-S-H) や水酸 化カルシウムを主成分とするセメント水和物において，化学吸着水 の放出など脱水反応が生じることによる ${ }^{16)}$ 。

気乾試験体および封かん試験体の蒸発性水分の蒸発が終了した $250^{\circ} \mathrm{C}$ 以降, 同じ水セメント比の気乾試験体と絶乾試験体では, 重量 減少率と試験体温度の関係から得る勾配が同等になった。試験体の 初期含水率が, $250^{\circ} \mathrm{C}$ 以上での重量減少に影響しないことは既往の研 究でも報告されている ${ }^{14)}$ 。一方, 図 5 に示すように, $250^{\circ} \mathrm{C}$ から $500^{\circ} \mathrm{C}$ にかけて, 水セメント比 $65 \%$ 封かん試験体における重量減少率の 増加は, 同じ水セメント比の気乾試験体・絶乾試験体の 1.2 倍程度 になった。また，同温度領域においては水セメント比が小さい試験 体ほど重量減少率の増加が大きくなり，水セメント比 $40 \%$ の試験体 の増加は水セメント比 $65 \%$ の 1.5 倍程度となった。封かん試験体や

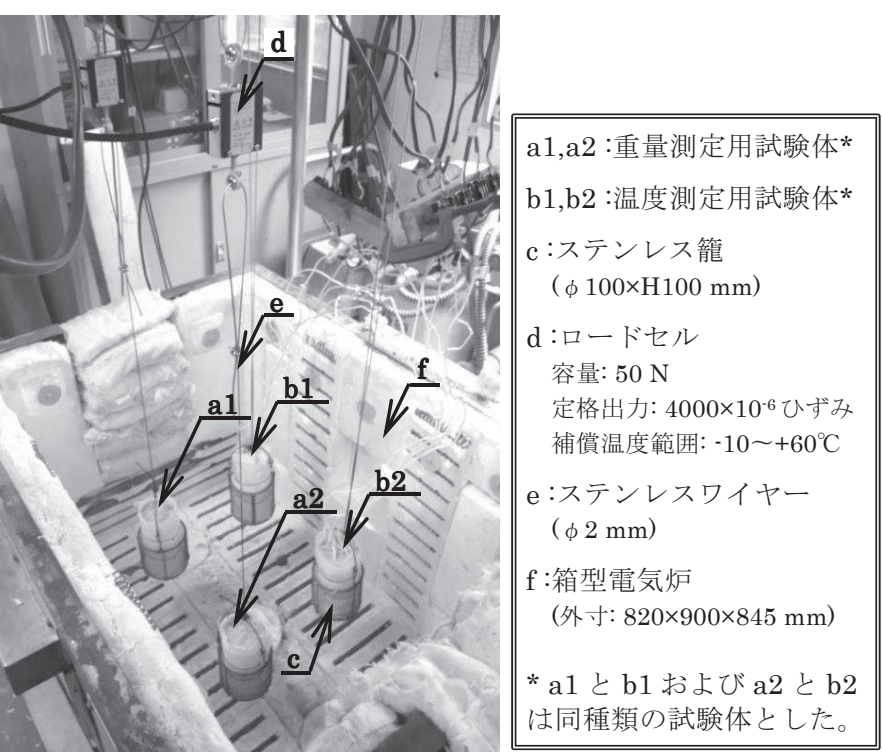

写真 1 重量減少測定実験装置（電気炉内の状況）

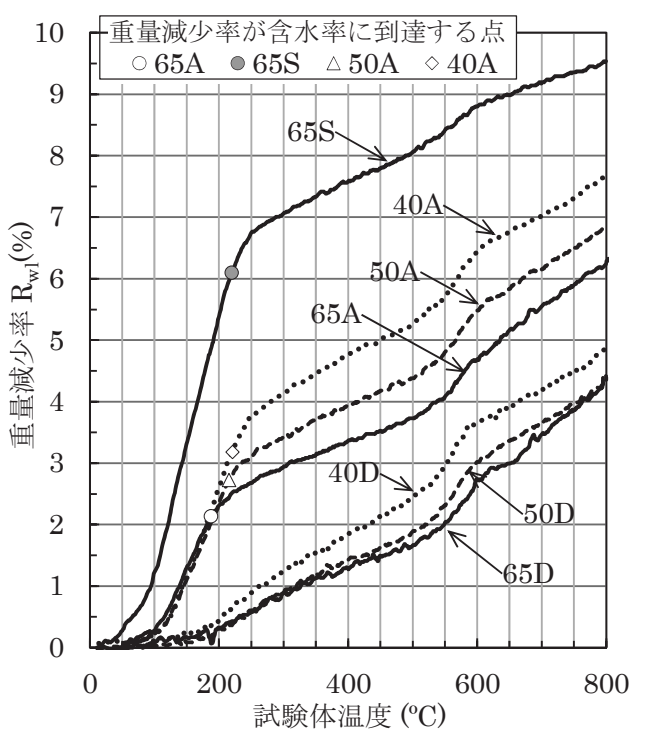

図 4 重量減少率と試験体温度の関係 
水セメント比が小さい試験体はセメント水和物の含有量が比較的多 いため, セメント水和物の脱水による重量減少が多くなったと考え られる。

$500^{\circ} \mathrm{C} \sim 600^{\circ} \mathrm{C}$ では，全ての試験体において重量減少率の勾配が急 になった。この要因として, 水酸化カルシウムの分解による重量減 少が考えられる。Anederberg らは, 試験体を $500^{\circ} \mathrm{C} て ゙$ 加熱した際, 水酸化カルシウムの分解による重量減少が時間の経過に伴い発生す ることを報告している ${ }^{4)} 。 600^{\circ} \mathrm{C}$ 以降では, セメント水和物内の化学 吸着水の放出は終了する一方 ${ }^{16)}$, ケイ酸カルシウム水和物 $(\mathrm{C}-\mathrm{S}-\mathrm{H})$ の分解 ${ }^{16)}$, 17) が発生する。重量減少測定実験で生じた試験体の反応と 温度の関係を表 5 にまとめる。

\section{4. 全ひずみ・熱膨張ひずみ}

\section{1 全ひずみ実験の概要}

表 6 に示すように，全ひずみ実験の実験要因は，水セメント比, 養生条件, 応力レベルとした。載荷応力 $\sigma$ は水セメント比毎に設定 し, 表 6 に示す気乾試験体の常温時圧縮強度 $\sigma_{\mathrm{b}}$ に応力レベルを乗じ た值とした。応カレベル 0 は無載荷加熱実験であり, 熱膨張ひずみ を測定するために行った。全ひずみ実験は，実験要因ごとに 1 体ず つ実施した。

全ひずみ実験で使用した実験装置は前報 ${ }^{2)}$ と同じである。全ひず み実験における試験体内部温度測定位置を図 6 に示す。全ひずみ実 験では, 熱電対の埋め込みが実験結果へ影響しないよう, 試験体表 面から深さ $6 \mathrm{~mm}$ の位置でのみ内部温度を測定した。試験体の加熱は, 試験体に設定応力レベルに相当する荷重を載荷した直後から開始し, 試験体の上下端部における表面温度（図 6 中の $\mathrm{T}_{1}, \mathrm{~T}_{2}$ ) が $1.5^{\circ} \mathrm{C} /$ 分 で昇温するように電気炉の加熱制御を行った。そして，試験体への 載荷荷重を一定に保ったまま, $\mathrm{T}_{1}, \mathrm{~T}_{2}$ の平均が $800^{\circ} \mathrm{C}$ に達するか, 試 験体が破壊するまで加熱を継続し，その間に生じる試験体の上下端 部間の鉛直相対変位を測定した。

- 印: 測定位置

$\mathrm{T}_{1} \sim \mathrm{T}_{12}$ : 各測定位置での 測定温度 $\left({ }^{\circ} \mathrm{C}\right)$

$\left(\mathrm{T}_{5} \sim \mathrm{T}_{12}\right.$ は, 内部温度分布 状況の確認時のみ測定)

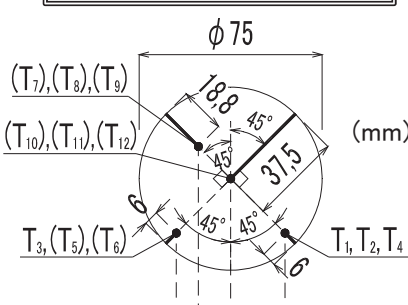

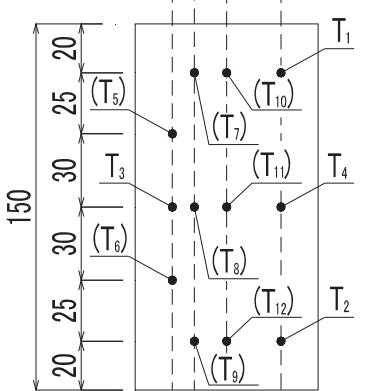

図 6 試験体内部温度測定位置 （全ひずみ実験）

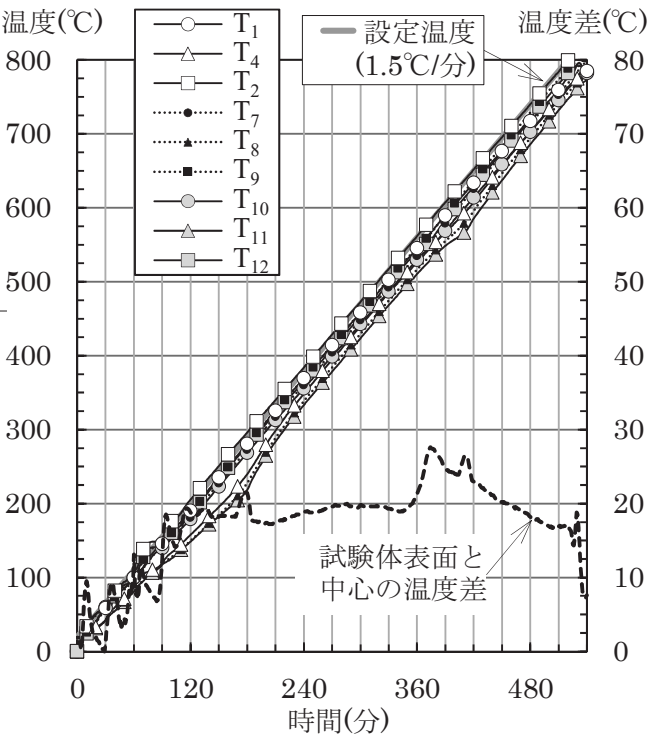

図 7 試験体内部温度と時間の関係 （全ひずみ実験における半径方向の温度分布）
全ひずみ実験時における試験体内部温度の分布状況を確認するた め, 全ひずみ実験と同じ加熱条件で試験体の加熱を行いながら, 図 6 中の $\mathrm{T}_{1} \sim \mathrm{T}_{14}$ の測定を行った。測定は水セメント比 $65 \%$ の気乾試験 体・絶乾試験体・封かん試験体について行った。封かん試験体の半 径方向および軸方向における温度分布の測定結果を図 7 および図 8 にそれぞれ示す。図 7 に示すように，試験体の半径方向では表面か ら中心に向かって温度がやや低くなるが、試験体表面と中心の温度

\section{表 5 実験で生じた試験体の反応と温度の関係}

\begin{tabular}{|l|l|}
\hline 試験体温度 & 試験体の反応 \\
\hline \hline $100 \sim 200^{\circ} \mathrm{C}$ & 気乾試験体の蒸発性水分の蒸発 \\
\hline $100 \sim 250^{\circ} \mathrm{C}$ & 封かん試験体の蒸発性水分の蒸発 \\
\hline $200 \sim 600^{\circ} \mathrm{C}$ & 化学吸着水の放出などセメント水和物の脱水 \\
\hline $500 \sim 600^{\circ} \mathrm{C}$ & $\mathrm{Ca}(\mathrm{OH})_{2}$ の分解 \\
\hline $600^{\circ} \mathrm{C} \sim 800^{\circ} \mathrm{C}$ & $\mathrm{C}-\mathrm{S}-\mathrm{H}$ の分解 \\
\hline
\end{tabular}

表 6 全ひずみ実験の実験条件

\begin{tabular}{|c|c|c|c|}
\hline $\mathrm{W} / \mathrm{C}$ & 養生条件 (試験体名) & 応力レベル $\sigma / \sigma_{b}$ & 加熱温度 \\
\hline \multirow{3}{*}{$65 \%$} & 気中養生 (65A) & \multirow{2}{*}{$\begin{array}{c}0 \cdot 0.1 \cdot 0.3 \cdot \\
0.5 \cdot 0.7\end{array}$} & \multirow{7}{*}{$\begin{array}{l}\text { 常温〜 } \\
800^{\circ} \mathrm{C}\end{array}$} \\
\hline & 事前乾燥 (65D) & & \\
\hline & 封かん養生 (65S) & \multirow{5}{*}{$\begin{array}{l}\text { 常温時圧縮強度 } \\
\sigma_{\mathrm{b}}\left(\mathrm{N} / \mathrm{mm}^{2}\right)^{2)}: \\
26.5(\mathrm{~W} / \mathrm{C}=65 \%) \\
37.0(\mathrm{~W} / \mathrm{C}=50 \%) \\
49.2(\mathrm{~W} / \mathrm{C}=40 \%)\end{array}$} & \\
\hline \multirow{2}{*}{$50 \%$} & 気中養生 (50A) & & \\
\hline & 事前乾燥 (50D) & & \\
\hline \multirow{2}{*}{$40 \%$} & 気中養生 $(40 \mathrm{~A})$ & & \\
\hline & 事前乾燥 (40D) & & \\
\hline
\end{tabular}

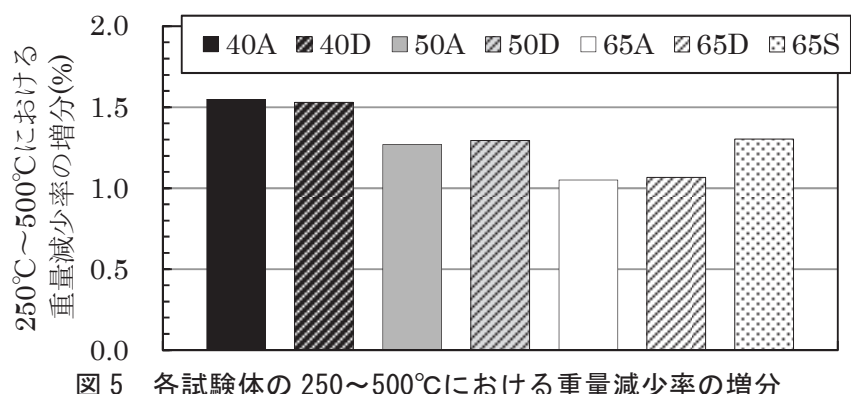

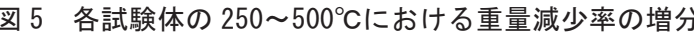

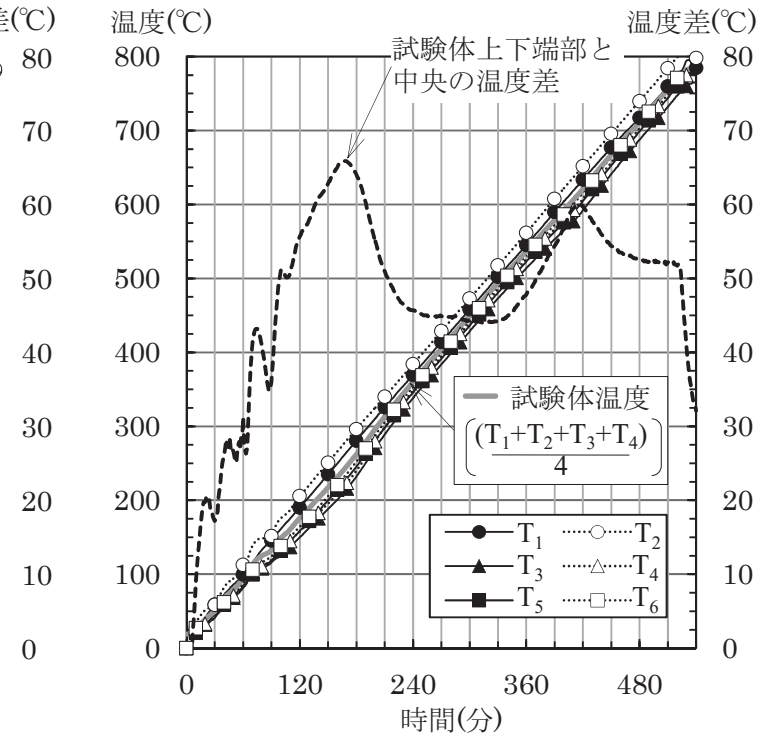

図 8 試験体内部温度と時間の関係 （全ひずみ実験における軸方向の温度分布） 
差は概ね $20^{\circ} \mathrm{C}$ 以下で推移し, $30^{\circ} \mathrm{C}$ 以上になることはなかった。一方, 図 8 に示寸ように, 試験体の軸方向では中央部は上下端部より温度 が低くなり、その温度差の最大は約 $60^{\circ} \mathrm{C}$ とった。本実験装置では, 試験体の上下端部に接する加力鋼材からの熱伝導により試験体を加 熱するため, 軸方向の試験体内部温度差が大きくなる。また, 昇温 過程では軸方向の温度分布は非線形な関係になるため, 図 8 に示寸 ように，上下端部と中央部の中間の温度（図 6 中の $T_{5}, T_{6}$ ) は中央部 の温度（図 6 中の $\mathrm{T}_{3}, \mathrm{~T}_{4}$ ) と同程度になった。気乾試験体と絶乾試験 体でも同様の傾向が見られた。以上の測定結果から, 試験体の半径 方向の温度分布は一様とみなし, 「試験体温度」は試験体表面から深 さ $6 \mathrm{~mm}$ の位置で測定した温度の平均值とした。また，軸方向におけ る非線形な温度分布を考慮し, 上端部, 下端部および中央部 2 点の 測定值から以下のように平均值を算出した。

$$
T_{t}=\left(T_{1}+T_{2}+T_{3}+T_{4}\right) / 4
$$

$T_{t}:$ 全ひずみ実験での試験体温度 $\left({ }^{\circ} \mathrm{C}\right)$,

$T_{1}, T_{2}, T_{3}, T_{4}$ : 試験体表面から深さ $6 \mathrm{~mm}$ での温度 (図 6 参照) ( ${ }^{\circ} \mathrm{C}$ ) なお，全ひずみ実験時における試験体の軸方向内部温度差は最大 で $73^{\circ} \mathrm{C}$ となり, RILEM が定めた全ひずみ実験方法 ${ }^{18)}$ における許容值 である $20^{\circ} \mathrm{C}$ りも大きくなった。ただし, 実験の再現性は高く, 各 実験における加熱性状のばらつきは小さかったことから, 以降に示 寸実験結果の相互比較による検討においては内部温度差の影響は小 さいと考えられる。

\section{2 全ひずみ・熱膨張ひずみと温度の関係}

応力レベル0の全ひずみ実験から得た熱膨張ひずみと試験体温度 の関係を図 9 に示す。熱膨張ひずみは, 温度に対して非線形に増加 するが， $600^{\circ} \mathrm{C}$ を超えると増加の勾配が緩やかになり， $800^{\circ} \mathrm{C}$ で約 $15000\left(\times 10^{-6}\right)$ のひずみとなった。この傾向は, 図 9 に示寸Eurocode ${ }^{19)}$ の提案值と概ね一致した。試験体の養生条件および水セメント比が 熱膨張ひずみへ及ぼす影響は見られなかった。

応力レベル 0 0.7 の全ひずみ実験から得た全ひずみと試験体温. 度の関係の一例として, 水セメント比 $65 \%$ の気乾試験体における測 定結果を図 10 に示す。なお, 図の縦軸は膨張ひずみを正, 収縮ひず みを負として表している。また, 載荷時熱ひずみの影響を分かりや

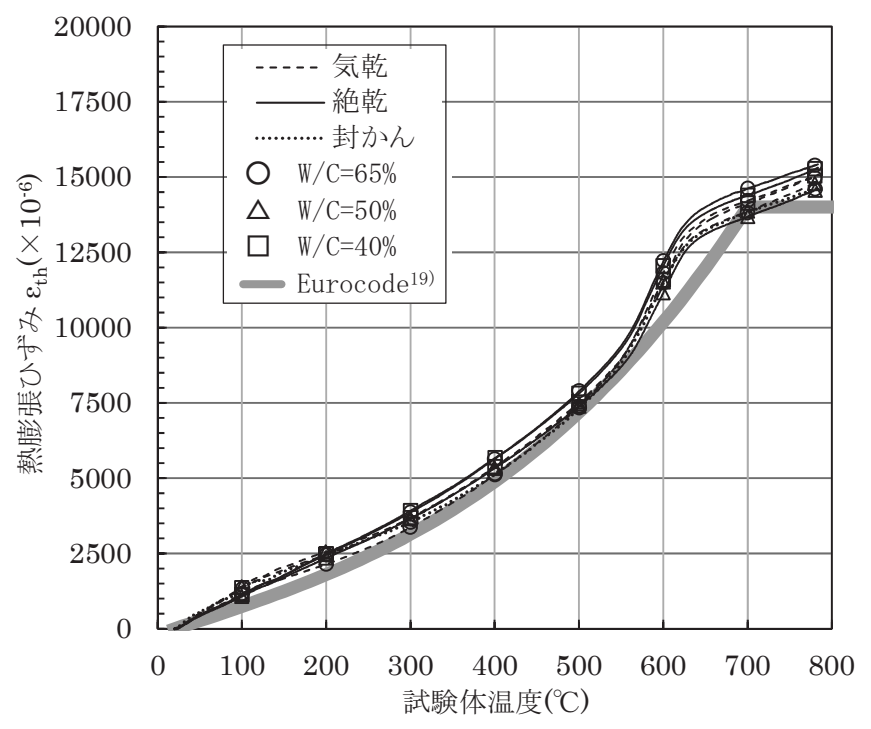

図 9 熱膨張ひずみと試験体温度の関係
すくするため, 初期応力ひずみは差引いて示した。応力レベル 00 実験で膨張側に発生する全ひずみは応力レベルの増加に伴い減少し， 応力レベル $=0.7$ の実験では概ね 0 となった。これは, 応力レベルの 増加に伴い載荷時熱ひずみが増大し，熱膨張ひずみを打消す程のひ ずみが生じたことを意味する。応力レベル 0.5 と 0.7 の実験では $800^{\circ} \mathrm{C}$ に到達する前に試験体が破壊した。次章では, 下式に示すよう に，全ひずみから熱膨張ひずみを差引くことで算出した載荷時熱ひ ずみについて考察する。

$$
\text { LITS }=\varepsilon_{t o t}-\varepsilon_{t h}
$$

LITS : 載荷時熱ひずみ, $\varepsilon_{t o t}$ : 全ひずみ, $\varepsilon_{t h}:$ 熱膨張ひずみ

\section{5. 載荷時熱ひずみ}

\section{1 養生条件の影響}

載荷時熱ひずみに及ぼす養生条件の影響を図 11 に示す。蒸発性水 分の蒸発が載荷時熱ひずみに及ぼす影響は， $100^{\circ} \mathrm{C} \sim 200^{\circ} \mathrm{Cにおいて}$ 顕著に表れた。気乾試験体では，蒸発性水分の蒸発が活発に生じる 約 $100^{\circ} \mathrm{C} \sim 200^{\circ} \mathrm{C}$ で載荷時熱ひずみが発生した。一方，絶乾試験体で は，約 $200^{\circ} \mathrm{C}$ まで載荷時熱ひずみはほとんど発生しなかった。気乾 試験体の蒸発が終了寸る $200^{\circ} \mathrm{C}$ 以降, 両試験体の差は一定，もしく は小さくなった。同様の傾向は，水セメント比が $35 \%$ 以下の高強度 コンクリートについても報告されている ${ }^{3), 8), 9)}$ 。また，既報 ${ }^{9)}$ と同 様, 約 $200^{\circ} \mathrm{C}$ までの温度域では, 両試験体の差は応力レベルが大き くなるほど増加し, 応力レベル $=0.7$ の実験では最大で約 $2500(\times$ $\left.10^{-6}\right)$ となった。 $100^{\circ} \mathrm{C} \sim 200^{\circ} \mathrm{C}$ で気乾試験体の載荷時熱ひずみが発生 したのは, 乾燥クリープが発生するためと考えられる。蒸発など水 分の移動がある状態で生じるクリープひずみは，水分の移動がない 状態で生じる場合よりも発生量が増大寸ることが知られており，こ の増分が乾燥クリープと呼ばれている ${ }^{20)}$ 。応力レベルが大きくなる と, 気乾試験体の乾燥クリープの発生量が多くなるため, 絶乾試験 体との差が増加したと考えられる。

水セメント比 $65 \%$ の封かん試験体では, 気乾試験体よりも載荷時 熱ひずみが増加する傾向が見られた。この傾向は $100^{\circ} \mathrm{C}$ を超えると 表れ始め, セメント水和物の脱水が始まる $200^{\circ} \mathrm{C}$ 程度からより顕著

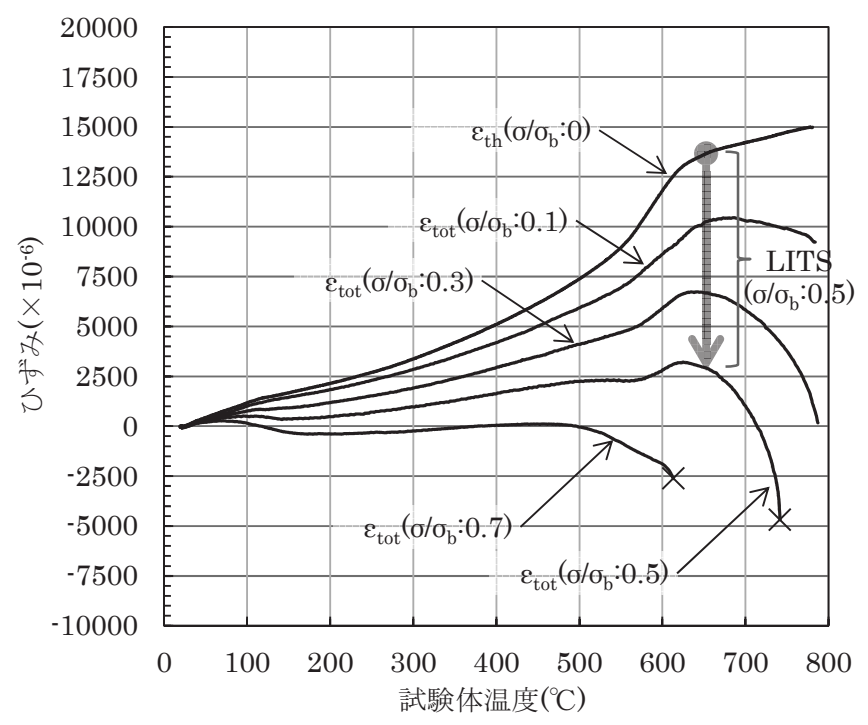

図 10 全ひずみ・熱膨張ひずみと試験体温度の関係（試験体名 : 65A） 
に表れた。両試験体の差は応力レベルが大きくなるほど増加し, 応 カレベル 0.7 の実験では約 $9000\left(\times 10^{-6}\right)$ に達した。封かん試験体と 気乾試験体の載荷時熱ひずみに差が生じた要因として, 載荷時熱ひ ずみを構成するひずみの一種である脱水クリープ 13) の発生量が両 試験体で異なることが挙げられる。 3.2 節で示したように, 封かん 試験体は気乾試験体よりもセメント水和物の脱水による重量減少率 の増加が大きいため, 脱水に伴い生じる脱水クリープの発生量が多 くなったと推察される。なお, 文献 3) において, 試験体の初期含水 率は $250^{\circ} \mathrm{C}$ 以上における載荷時熱ひずみに影響を及ぼさないことが 報告されている。

\section{2 水セメント比の影響}

載荷時熱ひずみに及ぼす水セメント比の影響を図 12 に示す。水セ メント比の違いによる影響は気乾試験体, 絶乾試験体ともに, セメ ント水和物の脱水が始まる $200^{\circ} \mathrm{C}$ 程度から顕著に表れた。試験体の
水セメント比が小さいほど載荷時熱ひずみが大きくなる傾向がみら れ, 応力レベル 0.3 の気乾試験体で比較すると, 水セメント比が $65 \%$ と $40 \%$ の試験体の差は $800^{\circ} \mathrm{C}$ で約 $10000\left(\times 10^{-6}\right)$ に達した。水セメン 卜比の違いによる差は応力レベルが大きくなるほど増加した。また, 応力レベル 0.5 と 0.7 における試験体の破壊温度は, 水セメント比 が小さい試験体ほど低くなる傾向が見られた。文献 11)では, 水セ メント比による影響は $300^{\circ} \mathrm{C}$ 以上で大きくなることが報告されてお り, その要因として, 高温時強度に対する載荷応力の比である有効 応力の変化などが挙げられている。本研究においても, 水セメント 比が小さい試験体ほど高温時強度残存率の低下が大きいため ${ }^{2)}$, 温 度上昇に伴い高温時圧縮強度に対する載荷応力の割合が大きくなる。 これにより載荷時熱ひずみ中の塑性ひずみが増大し, 破壊温度も低 下したと考えられる。ただし, 水セメント比の違いによる強度残存 率の低下が顕著になるのは $400^{\circ} \mathrm{C}$ を超えてからである ${ }^{2)}$ 。そのため,

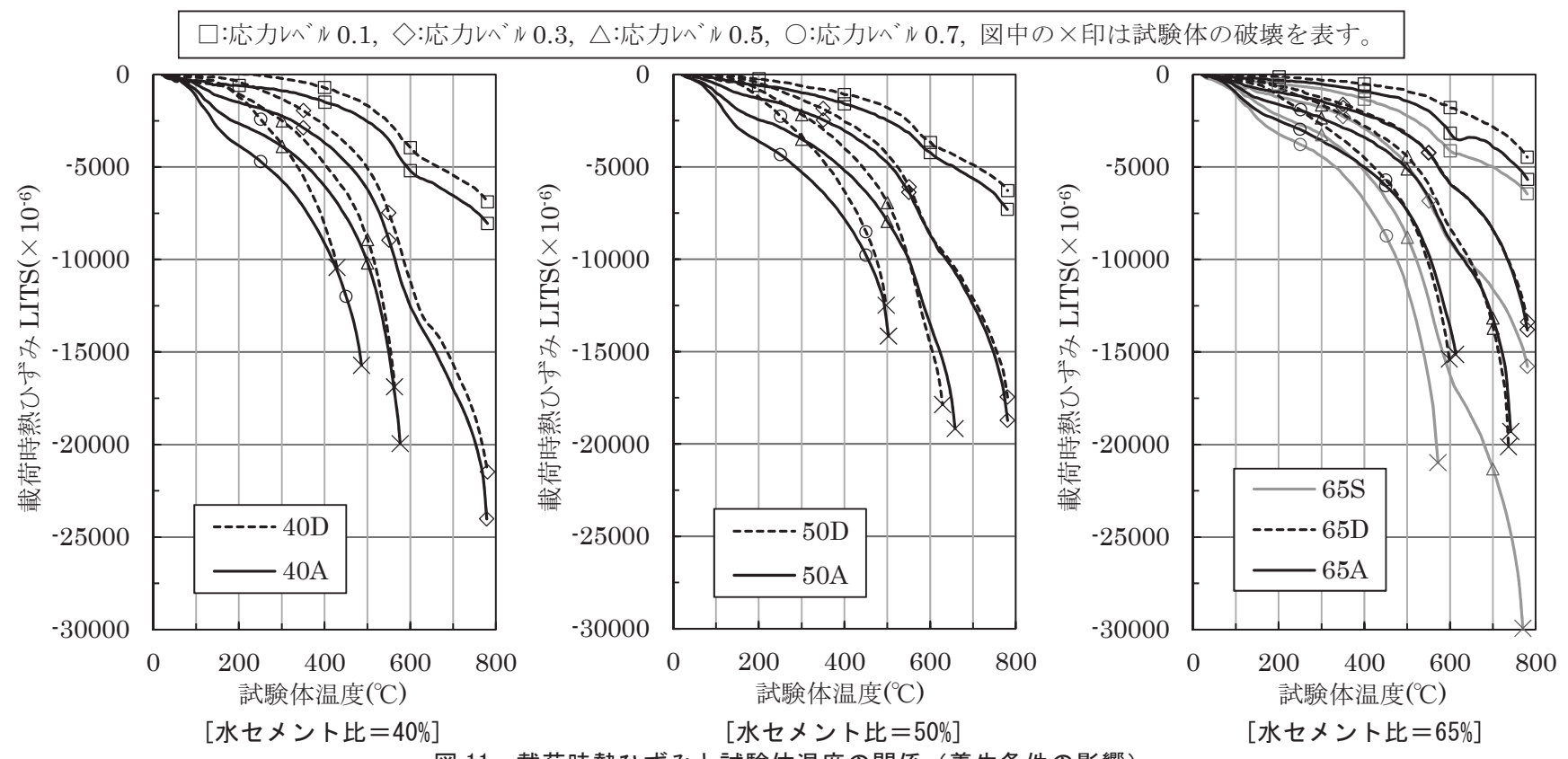

図 11 載荷時熱ひずみと試験体温度の関係（養生条件の影響）

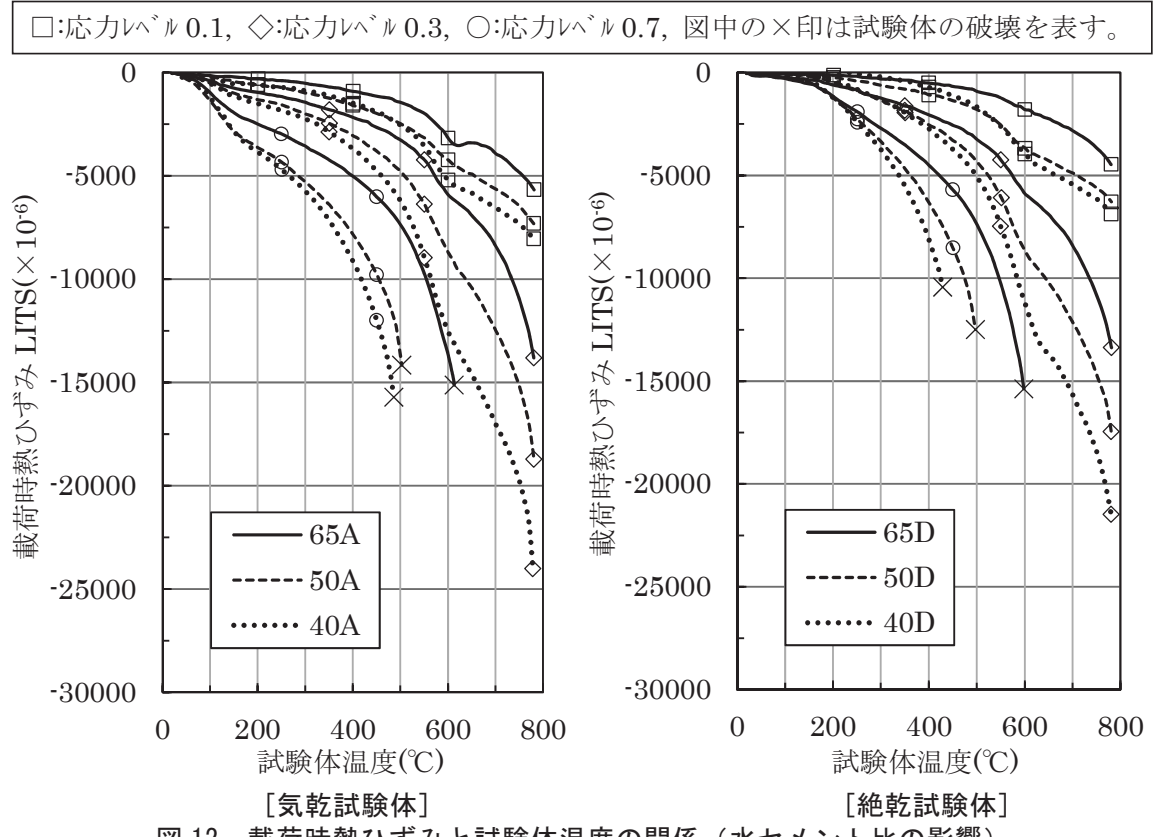

図 12 載荷時熱ひずみと試験体温度の関係（水セメント比の影響） 
より低い $200^{\circ} \mathrm{Cから} 400^{\circ} \mathrm{C}$ 温度域では, 試験体間の脱水量の違いに より脱水クリープの発生量が変化することで, 載荷時熱ひずみの差 が表れたと考えられる。

水セメント比の影響をより広く検討するため, 応カレベル 0.3 に おける載荷時熱ひずみについて, 本報と既報 ${ }^{9)}$ の結果を比較して図 13 に示す。既報で使用した試験体は, コンクリートの水結合材比が $18 \%, 24 \%, 35 \%$ の気乾試験体であり, 粗骨材は本報と同種の硬質砂岩で ある。既報では, $150^{\circ} \mathrm{C}$ 以上の温度域で本報よりも載荷時熱ひずみが 大きくなっているが，水結合材比の違いによる影響は明確でない。 試験体間の水セメント比の違いは本報 $(65 \% / 40 \%=1.6)$ よりも既報 (35\%/18\%=1.9)の方が大きいにもかかわらず, 載荷時熱ひずみの差の 最大值は本報（約 $\left.8000\left(\times 10^{-6}\right)\right)$ の方が既報（約 $6000\left(\times 10^{-6}\right)$ ) よ りも大きくなった。水セメント比が $38 \%$ 未満になると, 調合中のセ メント量を増やしても未水和セメント粒子が増えるばかりでセメン 卜水和物量はほとんど変わらない ${ }^{211}$ 。そのため既報の試験体では, 水結合材比の違いによる脱水量の差が小さい ${ }^{23)}$ 。また, 水結合材比 の違いが高温時強度残存率へ及ぼす影響も, 既報の試験体ではあま り表れていない2）これらの要因により, 既報では水結合材比によ る影響が小さくなったと考えられる。

\section{3 応カレベルの影響}

載荷時熱ひずみと応力レベルの関係を図 14 に示す。応力レベルが 0.4 以下の既往実験では, 載荷時熱ひずみは応力レベルに比例して 増加することが報告されている ${ }^{3), 15)}$ 。本報では，塑性ひずみの影響 が大きくなる応力レベル 0.5 と 0.7 の実験でも, 載荷時熱ひずみは 応力レベルと概㸚比例関係にあることが確認された。また, 試験体 の養生条件や水セメント比によらず, 載荷時熱ひずみは応力レベル と比例関係にあることも確認された。

\section{4 載荷時熱ひずみと重量減少率の関係}

5.1 節および 5.2 節では, 試験体温度との関係に基づき, 載荷時 熱ひずみに及ぼす養生条件および水セメント比の影響について考察 を行った。本節では, 試験体の重量減少との関係に基づき, 載荷時 熱ひずみの考察を行う。
載荷時熱ひずみと重量減少率の関係を図 15 に示す。図 15 に示す ように，載荷時熱ひずみと重量減少率の関係は養生条件ごとに分か れる。同じ養生条件で比較すると, 載荷時熱ひずみと重量減少率の 関係は水セメント比によらず同等であり，この性状は全ての応力レ ベルにおいて確認された。応力レベル 0.3 の関係では, 水セメント 比の違いによる載荷時熱ひずみの差は $5000\left(\times 10^{-6}\right)$ 以下であり, 図 12 に示す温度との関係における差（約 $\left.10000\left(\times 10^{-6}\right)\right)$ の半分以下 となった。

図 15 の応力レベル 0.3 の関係に示寸ように, 気乾試験体および封 かん試験体では, 重量減少率が表 4 亿示す各試験体の含水率に到達 するまで, 載荷時熱ひずみの増加は比較的小さい。この載荷時熱ひ ずみの大部分は蒸発性水分の蒸発に伴い生じる乾燥クリープと考え られる。一方, 各試験体の重量減少率が含水率を超えると, 載荷時 熱ひずみは重量減少率の増加に伴い急激に増加することが確認され た。このことから，載荷時熱ひずみの大部分はセメント水和物の脱 水および分解に伴うクリープであると考えられる。蒸発性水分を含 まない絶乾試験体の載荷時熱ひずみも大部分は脱水・分解に伴うク リープであり, 重量減少率の増加に伴い急増した。応力レベル 0.3 における, 重量減少率が含水率に到達する前に発生した載荷時熱ひ

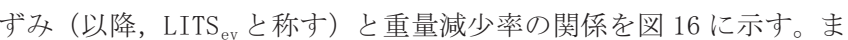
た, 重量減少率が含水率に到達した後に発生した載荷時熱ひずみ(以 降, LITS $_{\mathrm{dh}}$ と称寸) と重量減少率 $\mathrm{R}_{\mathrm{w} 1 . \mathrm{dh}}\left(=\mathrm{R}_{\mathrm{w} 1}\right.$-含水率 $)$ の関係も併 せて示す。絶乾試験体の載荷時熱ひずみは全て LITS $\mathrm{dh}$ とした。LITS は $\operatorname{LITS}_{\mathrm{ev}}$ の 10 倍以上の大きさとなることから，載荷時熱ひずみは セメント水和物の脱水や分解に伴い大きく増大寸るひずみであると 考えられる。これは, 既往の研究における指摘と一致する ${ }^{5), 7)}$ 。 LITS $_{\mathrm{dh}}$ と重量減少率の関係は，養生条件および水セメント比によらず概秝 同等であり, 図 16 に示すように 1 つの曲線に概数収れんした。これ より，載荷時熱ひず夕を重量減少率との関係で表すことで，試験体 の水セメント比や養生条件の違いによる影響を包含した関係を得ら れることが確認された。他の応力レベルにおいても, LITS $\mathrm{dh}$ と重量 減少率の関係からは上記と同様の性状が得られた。

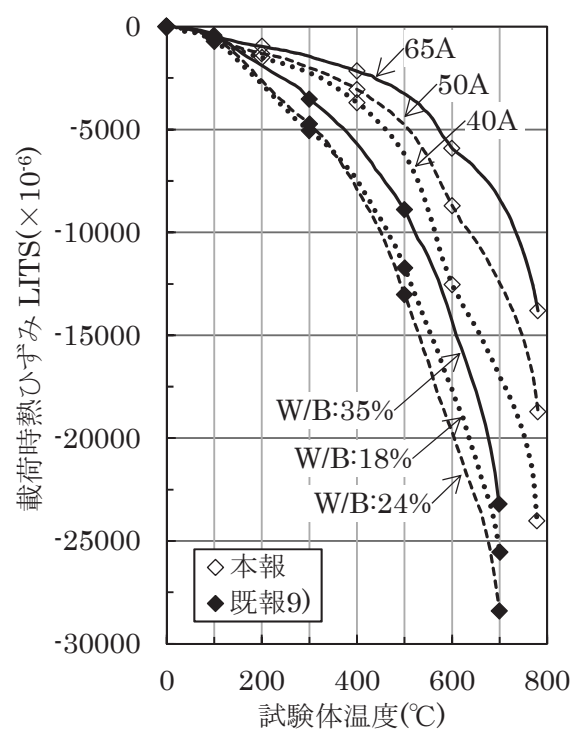

図 13 載荷時熱ひずみと試験体温度の関係 高強度コンクリート ${ }^{9)}$ との比較 応カレベル:0.3

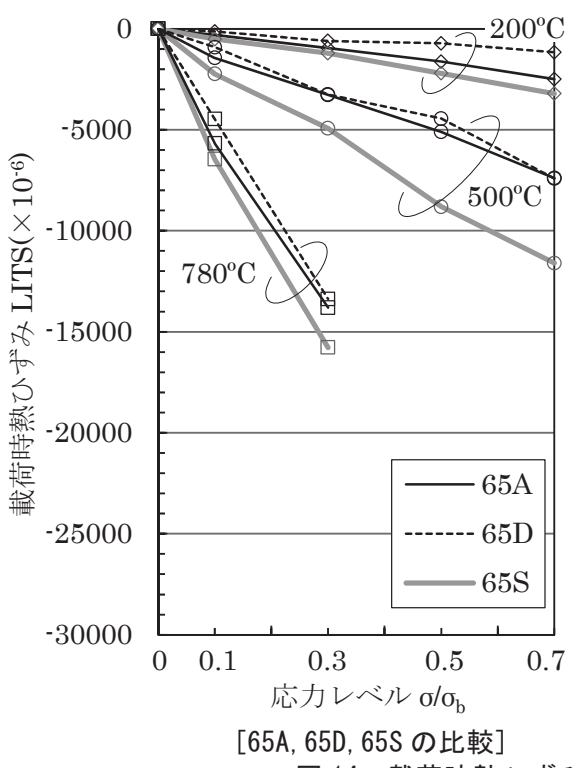

図 14 載荷時熱ひずみと応カレベルの関係

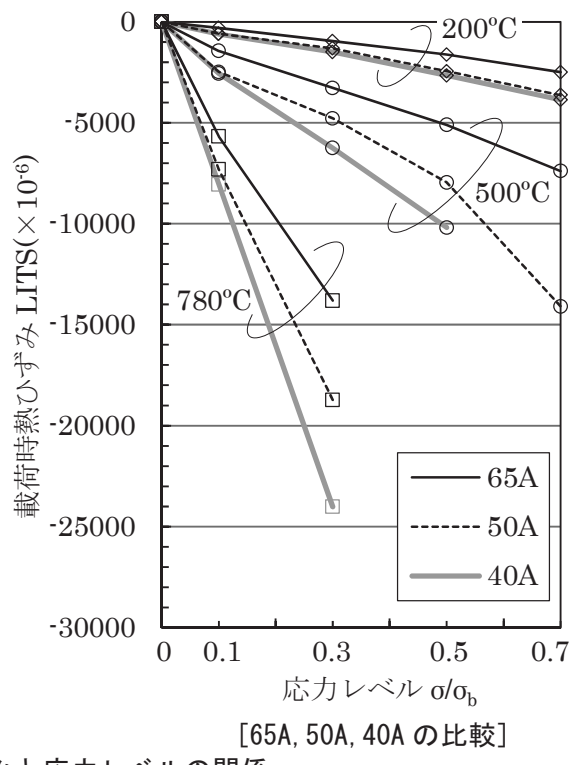

故, 50A, 40A の比較 

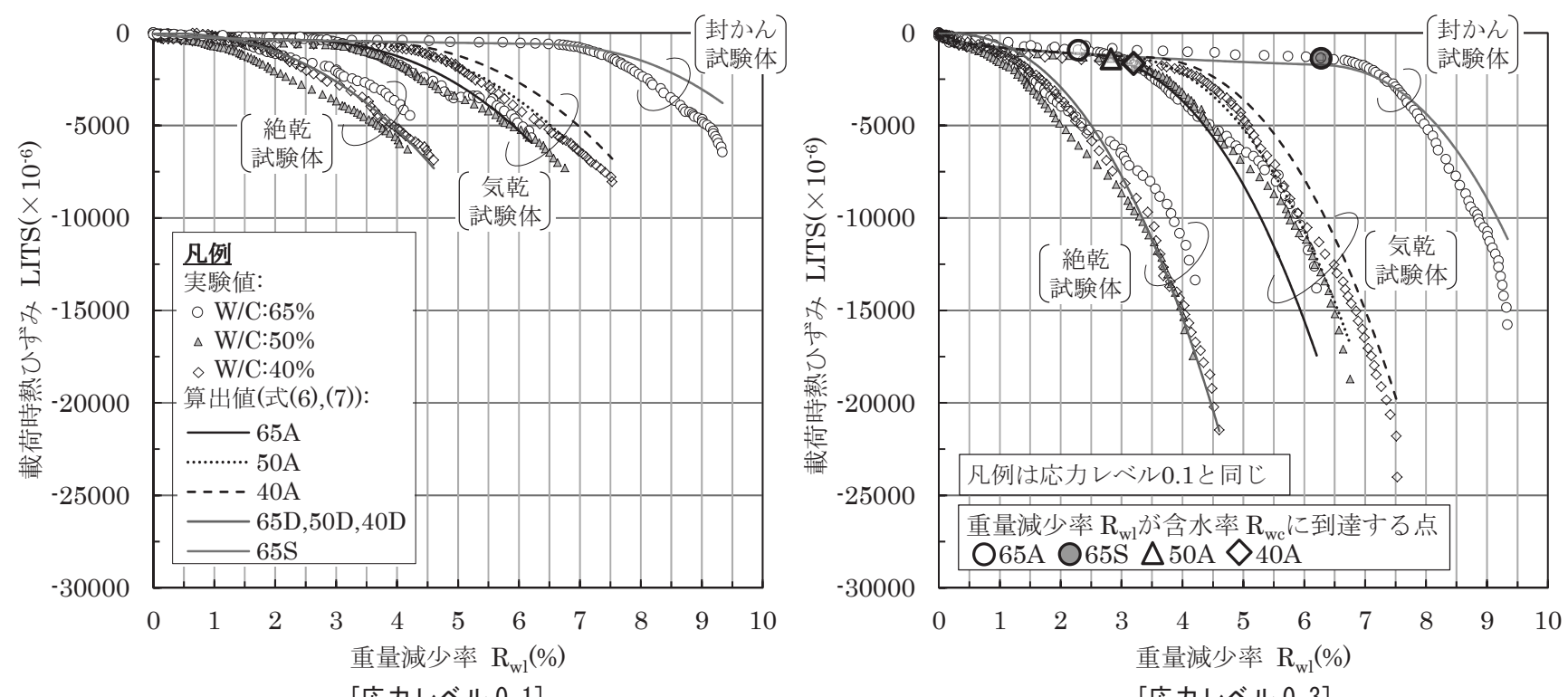

[応カレベル 0.1]
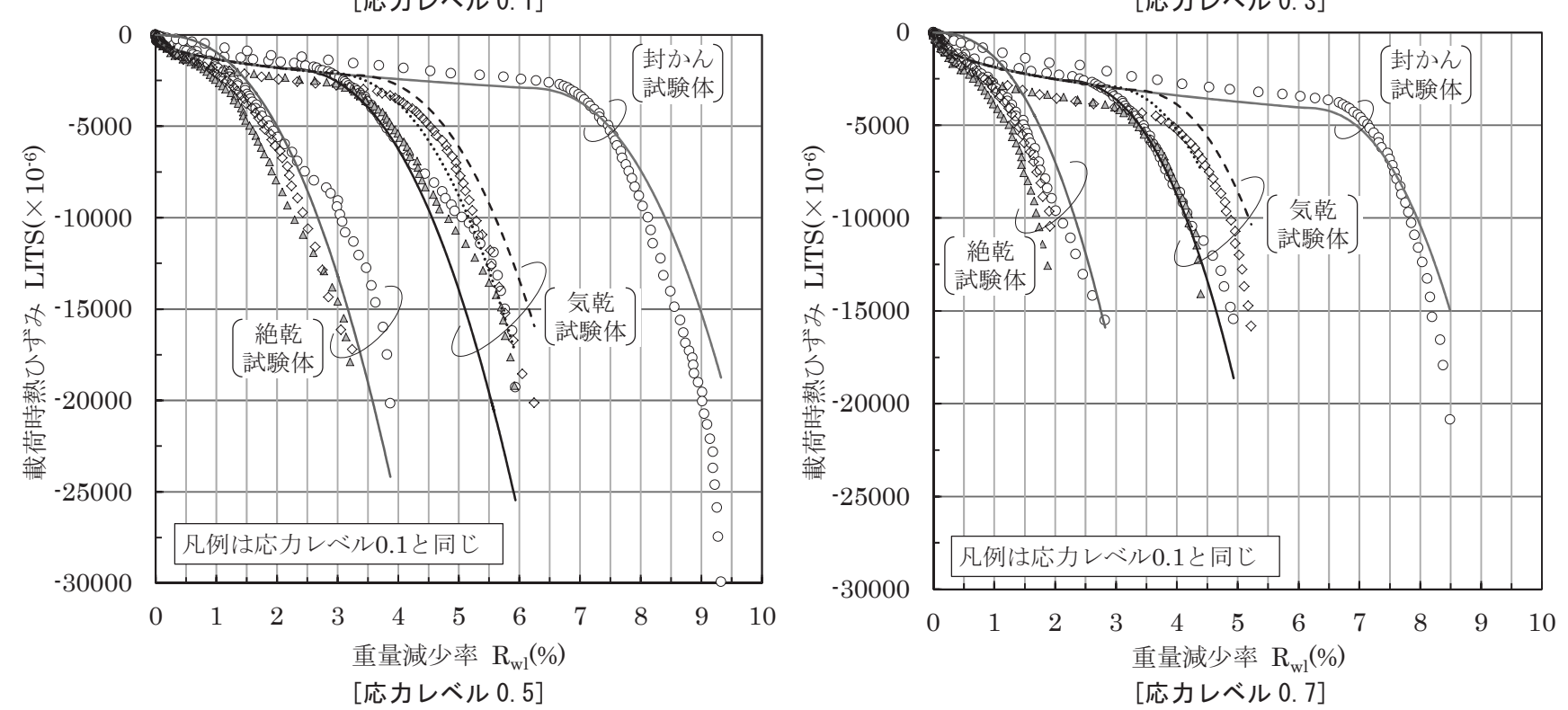

図 15 載荷時熱ひずみと重量減少率の関係

（実験値と算出値 (式 (6)，(7)）の比較）

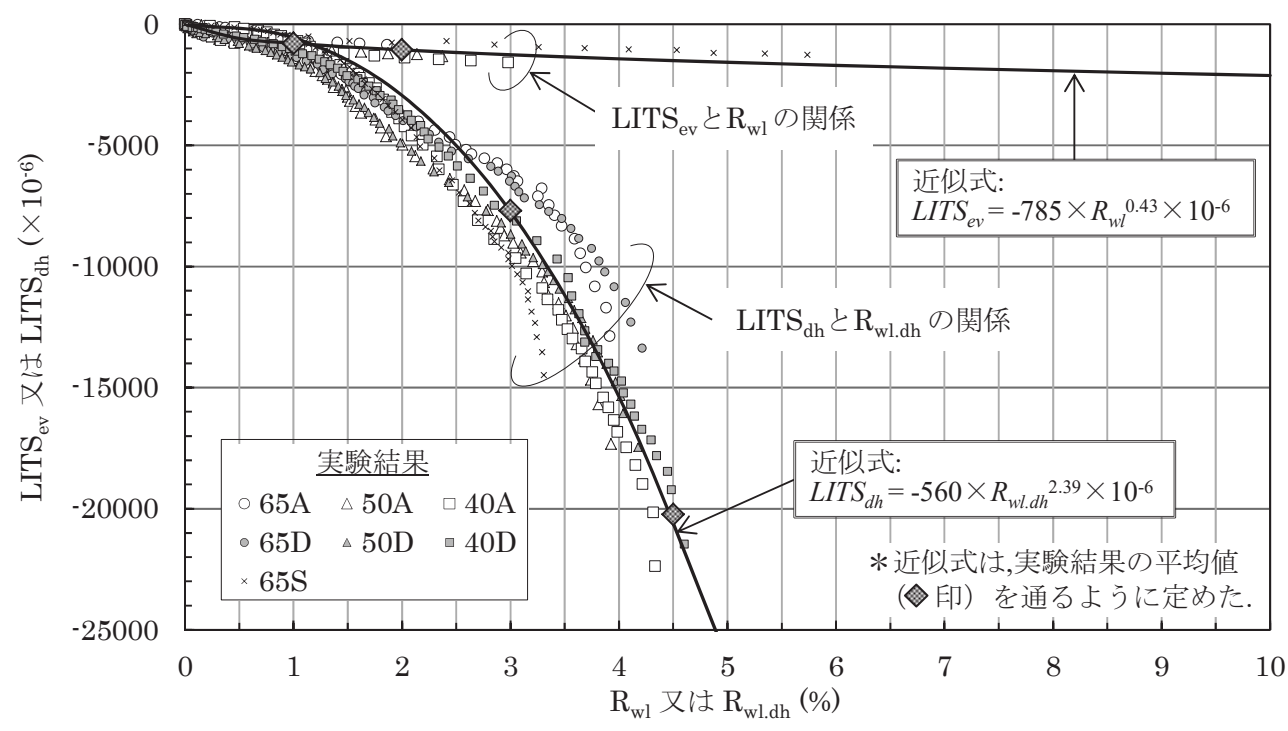

図 16 LITS $_{\mathrm{ev}} \cdot \mathrm{LITS}_{\mathrm{dh}}$ と重量減少率の関係(応カレベル：0.3) 


\section{6. 載荷時熱ひずみの数式化}

載荷時熱ひずみが応力レベルと比例関係にあることに着目した Terro は, 載荷時熱ひずみを応力レベル 0.3 の值で除すことで標準 化する方法を提案している ${ }^{6)}$ 。図 17 に, Terro の方法に倣い, 試験 体条件ごとに標準化した載荷時熱ひずみと応力レベルの関係を示す。 図 17 には下式により算出した值を示すが，0〜-1000 $\left(\times 10^{-6}\right)$ で除し た算出值はばらつきが大きくなるため除外した。

$\operatorname{LITS}_{\text {norm }}\left(R_{w l}\right)=\operatorname{LITS}\left(R_{w}, \sigma / \sigma_{b}\right) / \operatorname{LITS}\left(R_{w l}, 0.3\right)$

$\operatorname{LITS}_{\text {norm }}\left(R_{w l}\right)$ : 標準化した載荷時熱ひずみ

$\operatorname{LITS}\left(R_{w l}, \sigma / \sigma_{b}\right)$ : 応力レベル $\sigma / \sigma_{b}$ での載荷時熱ひずみ

$\operatorname{LITS}\left(R_{w l}, 0.3\right)$ : 応力レベル 0.3 での載荷時熱ひずみ

標準化した載荷時熱ひずみと応力レベルの間には，概ね同一の勾 配を持つ比例関係が見られた。これは，図 14 に示したように，養生 条件や水セメント比によらず載荷時熱ひずみと応力レベルは比例関 係にあるためである。この比例関係に基づき，標準化した載荷時熱 ひずみを応力レベルの一次関数として,図 17 に示すように近似した。 その際, 近似式を応力レベル 0.3 での值と原点を通る直線として定 めることで, 無載荷の状態では載荷時熱ひずみが生じない条件とし た。この近似式を用いて, 載荷時熱ひずみを応力レベル 0.3 での值 との比による関数として下式のように表した。

$\operatorname{LITS}\left(R_{w}, \sigma / \sigma_{b}\right)=3.4 \cdot \sigma / \sigma_{b} \cdot \operatorname{LITS}\left(R_{w}, 0.3\right)$

また, 図 16 に示すように, 応力レベル 0.3 での LITS $_{\mathrm{ev}}$ および LITS を重量減少率のべき関数としてそれぞれ近似した。式中の定数は, LITS $_{\mathrm{ev}}$ は $\mathrm{R}_{\mathrm{w} 1}$ が $1 \%$ と $2 \%$ の時の実験值の平均, LITS $\mathrm{dh}$ は $\mathrm{R}_{\mathrm{w} 1 . \mathrm{dh}}$ が $3 \%$ と 4. 5\%の時の実験值の平均を近似式が通るようにそれぞれ定めた。そ

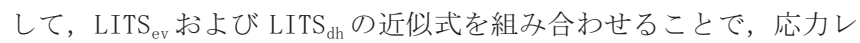
ベル 0.3 での載荷時熱ひずみを以下のように数式化した。

$$
\begin{aligned}
& \operatorname{LITS}\left(R_{w l}, 0.3\right)=-785 \times R_{w l}^{0.43} \times 10^{-6} \quad\left[R_{w l} \leqq R_{w c} \text { の場合 }\right] \\
& \operatorname{LITS}\left(R_{w l}, 0.3\right)=\left(-785 \times R_{w c}{ }^{0.43}-560 \times\left(R_{w l}-R_{w c}\right)^{2.39}\right) \times 10^{-6}
\end{aligned}
$$$$
\left[R_{w l}>R_{w c} \text { の場合 }\right]
$$

図 15 に,式(6)および式(7)を用いて算出した載荷時熱ひずみの值 と実験值の比較を示寸。 0.5 以下の応カレベルでは, 実験結果と算 出值は概ね一致する結果となった。一方, 応力レベル 0.7 では, 算 出值が実験值よりも小さくなるケースが見られた。これは, 図 17 に示すように, 応力レベル 0.3 に対する応力レベル 0.7 の載荷時熱 ひずみの比を実験值よりも小さめに見積もる形で数式化を行ったた めである。

\section{7. まとめ}

本報では, コンクリートの養生条件 (気中養生, 封かん養生, $105^{\circ} \mathrm{C}$ での事前乾燥）および水セメント比（40\%，50\%，65\%）がその載 荷時熱ひずみに及ぼす影響を, 加熱速度 $1.5^{\circ} \mathrm{C} /$ 分の全ひず夕実験お よび重量減少測定実験によって検討した。また, 実験から得られた 載荷時熱ひずみと試験体の重量減少率の関係を検討した。以下に本 研究から得られた知見を示す。

（1）コンクリート中の蒸発性水分の蒸発が載荷時熱ひずみに及ぼ 寸影響は $100^{\circ} \mathrm{C} \sim 200^{\circ} \mathrm{C}$ において顕著であり, 全ての水セメント 比において気乾試験体は絶乾試験体よりも載荷時熱ひずみが 大きくなった。

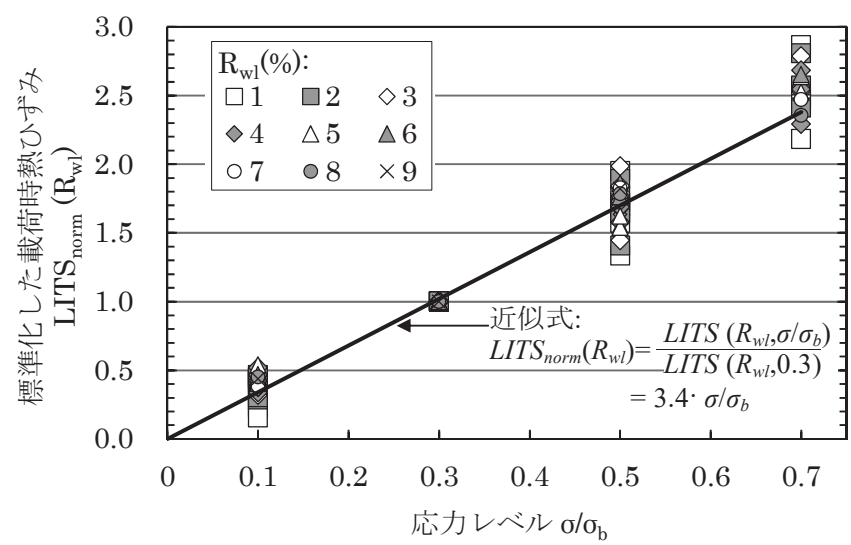

図 17 標準化した載荷時熱ひずみと応カレベルの関係

（2） $200^{\circ} \mathrm{C}$ 以上の温度域では，セメント水和物の脱水および分解が 載荷時熱ひずみに及ぼす影響が顕著になり，水セメント比 $65 \%$ では封かん試験体の載荷時熱ひずみが気乾試験体よりも大き くなった。また, 気乾試験体, 絶乾試験体ともに, 水セメント 比が小さくなると載荷時熱ひずみは大きくなった。

（3）載荷時熱ひずみへの影響は, 蒸発性水分の蒸発よりも, $200^{\circ} \mathrm{C}$ 以上の温度域で生じるセメント水和物の脱水および分解によ る方が著しく大きかった。

（4）応力レベルが $0.1 〜 0.7$ の範囲で，載荷時熱ひずみは，養生条 件や水セメント比によらず応力レベルに比例して増加した。

（5）以上の結果を踏まえ, 試験体の重量減少率を要因とした載荷時 熱ひずみの数式モデルを提案した。そして, 従来の温度を要因 としたモデルとは異なり, 提案モデルは本報で検討した養生条 件や水セメント比のコンクリートに対して汎用的に適用でき ることを示した。

次報その 3 では, 前報と本報の実験結果から得た応力ーひずみ関 係および全ひずみに関する構成則を用いてひずみ拘束実験の熱応力 解析を行い，本報で提案した載荷時熱ひずタモデルの妥当性をより 詳細に検討する予定である。

\section{謝辞}

本研究で報告した実験は, 後藤暁氏（当時 千葉大学学生, 現 東 京セキスイハイム株式会社）に協力いただき実施したものである。 ここに記して，感謝の意を表します。

\section{参考文献}

1) 日本建築学会 編: 構造材料の耐火性ガイドブック,p.79, 丸善, 2009.3

2) 山下平祐，常世田昌寿，鈴木澄江，白岩昌幸，平島岳夫：コンクリートの高 温時力学的特性に及ぼす養生条件と水セメント比の影響 コンクリートの 高温時特性に及ぼす水分の影響 その 1 , 日本建築学会構造系論文集 第 720 号, pp.385-393, 2016.2

3) Gavriel A. Koury, Brian N. Grainger, Patrick J.E. Sullivan: Strain of concrete during first heating to $600^{\circ} \mathrm{C}$ under load, Magazine of Concrete Research, Vol.37, No.133, pp.195-215, 1985.12

4) Anderberg Y. and Thelendersson S.: Stress and Deformation Characteristics of Concrete at High Temperature 2.Experimental Investigation and Material Behaviour Model, Division of Structural Mechanics and Concrete Construction, Lund Institute of Technology, Bulletin No.54, Lund, Sweden, 1976

5) Schneider U.: Concrete at High Temperatures - A general Review, Fire Safety Journal, 13, No1, pp.55-68, 1988 
6) Mohamad J. Terro: Numerical Modeling of the Behavior of Concrete Structures in Fire, ACI Structural Journal, pp.183-193, 1998

7) D. Gawin, F. Pesavento, B.A.Schrefler: Modelling of deformation of high strength concrete at elevated temperatures, Materials and Structures, pp.218-236, 2004

8) 右田周平, 平島岳夫, 前田孝一: 高強度コンクリートの高温時力学的特性 に及ぼすポリプロピレン繊維および水分の影響, コンクリート工学年次論 文集, Vol.34, No.1, pp.1126-1131, 2012

9) 山下平祐,平島岳夫, 吉田徹: 火災加熱を受ける超高強度コンクリートの力学 的特性に関する実験的研究-その 4.コンクリートの高温時全体ひずみに与える水 分の影響-, 構造工学論文集, Vol.61B, pp.1-7,2015

10) 丹羽博則, 長尾覚博, 江戸宏彰, 上杉英樹, 齊藤光: $20^{\circ} \mathrm{C} \sim 600^{\circ} \mathrm{C}$ までの高 温載荷加熱を受けるコンクリートのひずみ挙動, 日本建築学会大会学術講 演梗概集 A-2,pp.249-250, 1999.9

11) Jin Tao, Xian Liu, Yong Yuan, Luc Taerwe: Transient strain of self-compacting concrete loaded in compression heated to $700^{\circ} \mathrm{C}$, Materials and Structures, pp.191-201, 2013

12) 崔景喆, 金圭庸, 崔亨吉, 金武漢: 超高強度コンクリートの高温ひずみ特 性を考慮した提案式の検討，コンクリート工学年次論文集，Vol.37，No.1， pp.991-996, 2015

13) Hassen Sabeur, Fekri Meftah: Dehydration creep of concrete at high temperatures, Materials and Structures, pp.17-30, 2008

14) Gavriel A. Koury, Brian N. Grainger, Patrick J.E. Sullivan: Transient thermal strain of concrete: literature review, conditions within specimen and behaviour of individual constituents, Magazine of Concrete Research, Vol.37, No.132, pp.131-144, 1985.9
15) Jean-Christophe Mindeguia, Izabela Hager, Pierre Pimienta, Helene Carre, Christian La Borderie: Parametrical study of transient thermal strain of ordinary and high performance concrete, Cement and Concrete Research, pp.40-52, 2013

16) U. シュナイダー著, 森永繁, 山崎庸行, 林章二訳: コンクリートの熱的性 質，技報堂, 1983.12

17) G.F.Peng, S.Y.N.Chan, M.Anson: Chemical kinetics of C-S-H decomposition in hardened cement paste subjected to elevated temperatures up to $800^{\circ} \mathrm{C}$, Advances in Cement Research, pp.47-52, 2001

18) RILEM TC 129-MHT: Test methods for mechanical properties of concrete at high temperatures- Recommendations Part 7 Transient creep for service and accident conditions, Materials and Structures, Vol.31, pp. 290-295, 1998

19)Eurocode 2: Design of concrete structures Part1-2: General rules- Structural fire design, The European Standard EN1992-1-2, p.26, 2004

20) Z.P. Bazant, J.C. Chern: Concrete creep at variable humidity: constitutive law and mechanism, Materials and Structures, Vol.18, No.103, pp. 1-20, 1985

21) A. M. Neville: Properties of Concrete, pp.26-30, Person Education Limited, 2002

22）山下平祐，吉田徹，平島岳夫：火災時におけるコンクリートの全体ひず みに与える水分の影響, 日本建築学会大会学術講演梗概集 防火, pp.29-32, 2015.9

23) 吉田徹, 山下平祐，平島岳夫：火災加熱を受けるコンクリートの重量減 少, 日本建築学会大会学術講演梗概集 防火, pp.67-68, 2015.9 


\section{INFLUENCE OF CURING CONDITION AND WATER CEMENT RATIO ON LOAD-INDUCED THERMAL STRAIN OF CONCRETE}

Influence of water content on properties of concrete in high temperatures Part 2

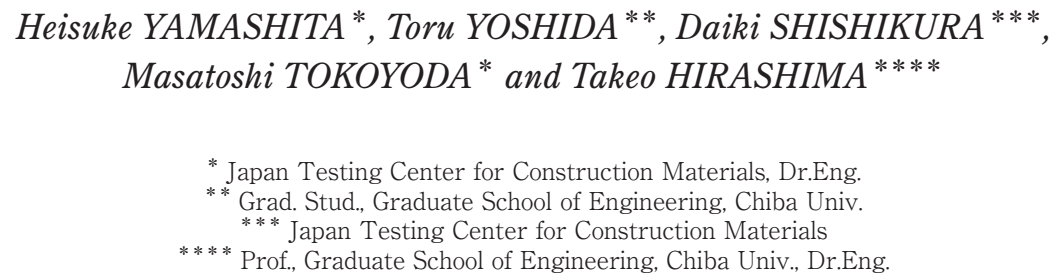

When concrete is heated under a sustained load, a large amount of shrinkage occurs to compensate for thermal expansion. This shrinkage was termed the load-induced thermal strain (LITS), and must be considered when performing a deformation analysis of reinforced concrete structures that are subjected to fire. In the constitutive strain models used in such analyses, the LITS is a function of the concrete temperature. However, the relationship between the LITS and temperature is influenced by the water of the concrete, making it difficult to apply these models to concrete with different water conditions. In the present study, the influence of the curing conditions (air-dried, oven-dried and sealed curing) and water/cement ratios (40\%, $50 \%$ and $65 \%$ ) on the LITS was investigated based on results obtained from the transient tests for measuring total thermal strain of concrete specimens. The relationship between the LITS and specimen weight loss was also evaluated in order to develop a comprehensive model for the LITS that is appreciable to concrete with different curing conditions and water/cement ratios.

In the transient tests for measuring total thermal strain, specimens ware heated at a constant rate of $1.5^{\circ} \mathrm{C} / \mathrm{min}$. up to $800^{\circ} \mathrm{C}$ under constant load. The ratio of the constant load to compressive strength of air-dried specimens at room temperature was settled between 0.1 and 0.7 . The LITS was calculated by subtracting value of the free thermal strain from the total thermal strain. The heating rate in the transient tests for measuring the weight loss was same as the tests of the total thermal strain. The main results obtained from the present study are as follows:

(1) The influence of the water evaporation on the LITS was evident between $100^{\circ} \mathrm{C}$ and $200^{\circ} \mathrm{C}$.

(2) The influence of the dehydration and decomposition of the cement hydrate on the LITS was evident above $200^{\circ} \mathrm{C}$.

(3) The LITS due to dehydration and decomposition was much larger than that due to water evaporation.

(4) The relationship between the LITS and load level was seen to be linear, regardless of the curing conditions or water/cement ratio.

(5) The numerical model for the LITS was proposed as a function of the weight loss of the specimens. And, it was indicated that the proposed model could be appreciable to concrete with different curing conditions and water/cement ratios. 